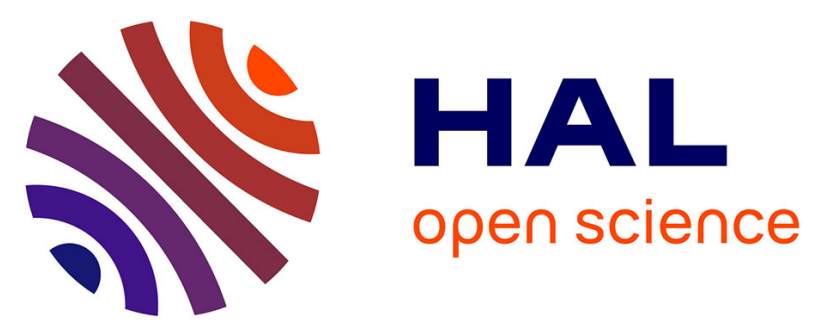

\title{
Non-conventional antiphospholipid antibodies in patients with clinical obstetrical APS: prevalence and pregnancies treatment efficacy
}

Arsène Mekinian, Marie-Charlotte Bourrienne, Lionel Carbillon, Amélie Benbara, Noémie Abisror, Sylvie Chollet-Martin, Ahmed Tigaizin, Francois

Montestruc, Olivier Fain, Pascale Nicaise-Roland

\section{To cite this version:}

Arsène Mekinian, Marie-Charlotte Bourrienne, Lionel Carbillon, Amélie Benbara, Noémie Abisror, et al.. Non-conventional antiphospholipid antibodies in patients with clinical obstetrical APS: prevalence and pregnancies treatment efficacy. Seminars in Arthritis and Rheumatism, 2016, 46 (2), pp.232-237. 10.1016/j.semarthrit.2016.05.006 . hal-01331255

\section{HAL Id: hal-01331255 \\ https://hal.sorbonne-universite.fr/hal-01331255}

Submitted on 14 Jun 2016

HAL is a multi-disciplinary open access archive for the deposit and dissemination of scientific research documents, whether they are published or not. The documents may come from teaching and research institutions in France or abroad, or from public or private research centers.
L'archive ouverte pluridisciplinaire HAL, est destinée au dépôt et à la diffusion de documents scientifiques de niveau recherche, publiés ou non, émanant des établissements d'enseignement et de recherche français ou étrangers, des laboratoires publics ou privés. 


\section{ACCEPTED MANUSCRIPT}

Non-conventional antiphospholipid antibodies in patients with clinical obstetrical APS: prevalence and pregnancies treatment efficacy

Mekinian Arsène ${ }^{1}$, Bourrienne Marie-Charlotte ${ }^{2}$, Carbillon Lionel $^{3}$, Benbara Amélie ${ }^{3}$, Noémie Abisror $^{1}$, Chollet-Martin Sylvie ${ }^{2}$, Tigaizin Ahmed ${ }^{3}$, Montestruc Francois ${ }^{4}$, Fain Olivier ${ }^{1}$, Nicaise-Roland Pascale ${ }^{2}$.

${ }^{1}$ AP-HP, Hôpital Saint-Antoine, service de médecine interne and InflammationImmunopathology-Biotherapy Department (DHU i2B), Sorbonne Universités, UPMC Univ Paris 06, F-75012, Paris, France

${ }^{2}$ Unité Fonctionnelles d'Immunologie «Auto-immunité et Hypersensibilités », AP-HP, Hôpital Bichat-Claude Bernard, Paris, France.

${ }^{3}$ Service de gynécologie-obstétrique, Université Paris 13, AP-HP, Hôpital Jean Verdier, 93140, Bondy, France

${ }^{4}$ eXYSTAT, Malakoff, 92240, France

Original research article: extended report

Correspondence and reprint request to: Arsène Mekinian, ${ }^{1}$ AP-HP, Hôpital Saint-Antoine, service de médecine interne and Inflammation-Immunopathology-Biotherapy Department (DHU i2B), Sorbonne Universités, UPMC Univ Paris 06, F-75012, Paris, France

Email: arsene.mekinian@aphp.fr

Running title: non-conventional APL in clinical obstetrical APS 


\section{ACCEPTED MANUSCRIPT}

Key words: antiphospholipid syndrome; non-conventional antiphospholipids; obstetrical complications; pregnancies treatment

\section{Abstract \\ Objectives}

To describe the prevalence of non-conventional APL in patients with obstetrical APS without conventional APL and the impact of treatment on pregnancy outcome.

\section{Methods}

Patients with clinical obstetrical criteria were tested for anti-phosphatidylethanolamine (aPE) $\mathrm{IgG} / \mathrm{M}$, anti-prothrombin/phosphatidylserine (anti-PS/PT) $\mathrm{IgG} / \mathrm{M}$ and anti-annexin $\mathrm{V}$ IgG. Pregnancies losses rates were compared between APS, non-conventional APS and non-APL and in untreated pregnancies to treated ones for each group.

\section{Results}

Using the cut-offs (ROC), 65/96 (68\%) patients have been considered as non-conventional APS and compared to 83 APS and 31 patients without APL. The obstetrical history in nonconventional APS did not differ in comparison to confirmed APS. The frequencies of antiannexin V IgG antibodies tended to be more frequent in non-conventional APS (88\% versus $73 \% ; \mathrm{p}=0.06$ ), and those of anti-PE IgG and $\mathrm{M}$ were similar. The anti-PS/PT IgG and $\mathrm{M}$ antibodies were more frequent in confirmed APS than in non-conventional APS $(63 \%$ and $37 \%$ versus $4 \%$ and $5 \%, \mathrm{p}<0.0001$ ).

Overall 261 pregnancies in patients with non-conventional APS were compared to 81 pregnancies of confirmed APS and 132 pregnancies from non-APL group. 136/474 (29\%) patients have been treated during pregnancies and treatment significantly increased the rate of live birth $(26 \%$ in untreated versus $72 \%$ in treated pregnancies, $\mathrm{p}<0.0001)$. In univariate analyses, treatment effect on pregnancies losses was similar in patients with APS and nonconventional APS, with odds ratio at 3.3 [95\% CI; 1.8 to 6.1 ] and 6.9 [95\% CI; 3.9 to 12.3 ] $(\mathrm{p}=0.49)$ and significantly more important for the 2 APS groups pooled versus non-APL group (OR at 1.9 [95\% CI; 1.1 to 3.5] for non-APL group versus 5.3 [95\% CI; 3.5 to 8.1] for APS groups, $\mathrm{p}=0.0025)$.

\section{Conclusion}

In this study $68 \%$ of patients with clinical criteria for obstetrical APS seronegative for conventional APL have non-conventional APL. These patients have a significant decrement of pregnancy losses if they receive treatment for APS during their pregnancy. 


\section{ACCEPTED MANUSCRIPT}

\section{INTRODUCTION}

Antiphospholipid syndrome (APS) is characterized by the presence of thrombosis and/or obstetrical adverse events and persistent antiphospholipid antibodies (APL). The conventional APL include lupus anticoagulant (LA), Ig G/M anticardiolipin antibodies (ACL), and anti$\beta_{2}$ glycoprotein-I ( $\left.\beta 2 \mathrm{GPI}\right)$ antibodies[1]. A seronegative APS have been described in patients with obstetrical and thrombotic APS symptoms without detectable conventional APL [2]. Several non-conventional antiphospholipid antibodies, like anti-phosphatidylethanolamine (aPE) and anti-annexin $\mathrm{V}$ antibodies, have been described, but few clinical data are available with controversial results. Among 2790 patients with recurrent miscarriage and implantation failure, IgG antiphosphatidylinositol, antiphosphatidylcholine, but not antiphosphatidylserine and aPE antibodies have been more frequent than in 205 fertile women [3]. In patients with early recurrent miscarriage, only aPE IgM and anti-annexin V IgG have been found to be associated with recurrent miscarriage [4]. [5][5] Studies are lacking to determine the cut-offs of non-conventional APL in particular in obstetrical subset and demonstrate the benefit of treatment to improve the obstetrical outcome.

We aimed (1) to describe the prevalence of non-conventional APL in patients with obstetrical APS criteria without conventional APL, in comparison to healthy pregnant women and APS patients; and (2) compare the pregnancy outcome between patients with non-conventional APL antibodies, APS, and patients with clinical obstetrical criteria for APS without any APL antibody.

\section{PATIENTS AND METHODS}

\section{Patients}

A prospective registry of patients with clinical obstetrical criteria (Sydney) was initiated from January 2010 until March 2014. The inclusion criteria were: (1) $\geq 3$ early miscarriages less than 10 weeks of gestation; (2) intrauterine fetal death $\geq 10$ weeks of gestation; (3) preeclampsia, prematurity $<34$ weeks of gestation related to placental insufficiency; (4) absence of inherited thrombophilia (V Leiden and II homozygous mutations, proteins $\mathrm{C}, \mathrm{S}$, ATIII deficiencies) and of conventional APL (LA, ACL IgG/M, anti- $\beta_{2}$ GPI IgG/M).

Maternal age, clinical APS features, associated autoimmune diseases, course and outcome of all pregnancies, treatments before and during all available pregnancies, and delivery mode during the last pregnancy were recorded. Neonatal outcome was assessed with following parameters for the last available pregnancy: gestational age at delivery, birth weight, 1- and 5minute Apgar scores, and presence of neonatal complications. 
Antiphospholipid antibodies assays

All women were tested for the presence of lupus anticoagulant (LA), IgG/IgM ACL and IgG/IgM anti- $\beta_{2}$ GPI antibodies. LA was detected using diluted Russell's viper Venom and diluted activated partial thromboplastin time as screening tests in accordance to ISTH recommendations. ACL IgG/M and anti- $\beta_{2}$ GPI $\operatorname{IgG} / \operatorname{IgM}$ were determined by two commercial ELISA from Inova Diagnostics (QUANTA Lite ACA, San Diego, CA) and ThermoFisher Scientific (Varelisa $\beta_{2}$ GPI, Saint Quentin en Yvelines, France), respectively. ACL IgG/M and anti- $\beta_{2}$ GPI antibodies IgG/M positivity was defined as value above $99^{\text {th }}$ percentile [6]. Triple positivity was defined by the association of a positive LA test, a positive ACL (IgG and/or $\operatorname{IgM})$ and a positive anti- $\beta_{2}$ GPI (IgG and/or IgM).

Non-conventional APL were tested and consisted in anti- aPE Ig G/M, antiprothrombin/phosphatidylserine (anti-PS/PT) IgG/M and anti-annexin V IgG APL. They were determined by commercial ELISAs using ELISIS P-Ethanolamine and ELISIS-Annexin V (Theradiag, Croissy Beaubourg, France) and QUANTA Lite aPS/PT (Inova, San Diego, CA) and expressed as $\mathrm{U} / \mathrm{ml}$. IgA anti- $\beta 2 \mathrm{GPI}$ antibodies and anti-domain I $\beta 2 \mathrm{GPI}$ antibodies were determined by QUANTA Flash $\beta 2$ GPI IgA and $\beta 2$ GPI-Domain I (BioFlash, Inova, San Diego, CA) and expressed as chemoluminescent units (CU). All assays were performed according to the manufacturer's instructions.

This study was approved by the University Hospital of Jean Verdier Institutional Review Board and the Comité de Protection des Personnes (CPP, Aulnay Sous Bois, 2003).

\section{Study groups}

Women with obstetrical and/or thrombotic events fulfilling APS Sydney criteria, but seronegative for conventional APL antibodies ( $n=96$ ) were evaluated for identify nonconventional APL antibodies A control group of 47 healthy pregnant patients without any pregnancy complication have been selected from Bichat Hospital, without any age difference with clinical APS and without conventional APL ( $31 \pm 6$ versus $33 \pm 4$ years; $p>0.05$ ).

A control group of patients with confirmed APS (Sydney criteria) $(n=83)$ was also selected.

The general characteristics, pregnancies and treatment during the pregnancies of patients with non-conventional APS, non-APL group and patients with confirmed APS were compared.

Sample size

The primary objective of this study was to identify the prevalence of non-conventional APL antibodies in patients that met obstetrical APS criteria, but were seronegative for conventional APL antibodies. For this expected prevalence of $90 \%, 65$ patients in the non-conventional APS group are necessary to estimate this proportion, with a two-sided $95 \%$ confidence interval and a precision of $7 \%$

\section{Data and statistical analysis}

All quantitative data are expressed as means with standard deviation (SD), while qualitative data are expressed as frequencies with percentages. The Fisher's exact test was used to compare qualitative variables, while one way analysis of variance F test or Student's t-test was used for continuous variables. To determine the cut-offs of non-conventional APL, ROC analysis has been performed in patients with clinical APS without conventional APL and 


\section{ACCEPTED MANUSCRIPT}

healthy pregnant controls. The cut-off which maximized sensitivity+ (1-specificity) was chosen.Univariate analyses and multivariate analyses (logistic models) were done to determine the factors associated with pregnancy losses. Odds ratios with their 95\% confidence intervals were calculated. In order to take into account multiple pregnancies for the same patient, multivariate general linear models were done in addition (SAS Proc Genmod). The factors analyzed in univariate analysis included patients' age, type of obstetrical events, any treatment during the pregnancy, treatment regimen, patients' group (APS, patients with clinical APS and non-conventional APL, patients with clinical APS without any antibodies or thrombophilia), presence of previous thrombosis, number of normal and pathological pregnancies. Factors were included in multivariate analysis if $p<0.05$ in univariate analyses then stepwise method was used to determine the final multivariate model.

Statistical analysis was performed using SAS (version 9.4; SAS Institute, Cary, NC), and significance was defined as $\mathrm{p}<0.05$.

\section{RESULTS}

\section{Non-conventional APL cut-offs in patients with pregnancy morbidity without conventional APL}

During the study, 96 patients with clinical APS (Sydney criteria) without any detectable thrombophilia (proteins C, S ATIII, factors II and V homozygous mutations, conventional APL), have been tested for non-conventional APL. Among them, recurrent miscarriage was noted in $44(46 \%)$ cases, intrauterine fetal deaths in $38(40 \%)$ cases, premature term $<34$ weeks of gestation in 25 (27\%) cases, preeclampsia and/or HELLP syndrome in 25 (26\%) cases and thrombosis in $14(15 \%)$ cases. Mixed thrombotic and obstetrical features were present in 15 patients (15\%) and isolated obstetrical features in remaining patients $(85 \%)$. Associated auto-immune disease was noted in 10 cases (10\%), mainly Sjogren's syndrome $(n=4)$ and thyroiditis $(n=4)$.

The mean levels of anti-Annexin IgG levels were at $7.7 \pm 6.1 \mathrm{U} / \mathrm{ml}$ in patients with clinical APS versus $2.2 \pm 1.9 \mathrm{U} / \mathrm{ml}$ in controls $(\mathrm{p}<.0001)$, anti-PE IgG at $7.3 \pm 7.1 \mathrm{U} / \mathrm{ml}$ versus $2.5 \pm 2.2$ $\mathrm{U} / \mathrm{ml}(\mathrm{p}<0.0001)$, anti-PE $\operatorname{IgM}$ at $8.8 \pm 11.9 \mathrm{U} / \mathrm{ml}$ versus $5.5 \pm 5.8 \mathrm{U} / \mathrm{ml}(\mathrm{p}=0.07)$, without any significant difference for anti-PS/PT IgG and M mean levels between the groups.

As there is no established cut-offs for non-conventional APL, ROC analysis has been performed to determine the cut-offs for each non-conventional APL (Table 1, Figure 1). The cut-offs of non-conventional antibodies were determined using ROC analysis for each antibody in comparison to healthy pregnant women without any obstetrical adverse event and without any detectable thrombophilia $(n=47)$. Among these 96 patients with clinical APS without conventional APL, using the established cut-offs (ROC analysis), 65/96 (68\%) patients have been considered as non-conventional APS (p.e clinical Sydney APS criteria with at least one non-conventional APL) and 31/96 remaining patients fulfilled clinical Sydney criteria without detectable conventional and non-conventional APL (non-APL group). Antiannexin V IgG and anti-PE IgG were sufficient to discriminate patients with clinical APS from controls with the cut-off at $6 \mathrm{U} / \mathrm{ml}$ (Figure 1). With this cut-off, when anti-annexin $\mathrm{V}$ $\mathrm{IgG} \leq 6 \mathrm{U} / \mathrm{ml}$ and anti-PE $\mathrm{IgG} \leq 6 \mathrm{U} / \mathrm{ml}$, then $43 / 69$ (62\% corresponding to a percentage of $38 \%$ of false negative) were patients without clinical APS. If Anti-annexin V IgG $>6 \mathrm{U} / \mathrm{ml}$ or 


\section{ACCEPTED MANUSCRIPT}

anti-PE IgG $>6 \mathrm{U} / \mathrm{ml}$, then $62 / 66$ (94\% corresponding to a percentage of $6 \%$ of false positive) were patients with clinical APS. Sensitivity of the test was $74 \%$ and specificity $91 \%$, with Yule's coefficient of colligation at 0.92 indicating a strong relationship between the level of anti-annexin V IgG and anti-PE IgG and the presence of clinical APS.

\section{Comparison of non-conventional APS to confirmed APS and non-APL group}

\section{Patients Characteristics}

The 65 patients with non-conventional APS have been compared to 83 patients with confirmed APS and 31 non-APL patients (Table 2). The conventional APL in patients with confirmed APS were lupus anticoagulant in 18 (36\%) cases, ACL IgG/M in 62 (79\%) and 13 $(23 \%)$ cases and anti- $\beta 2 \mathrm{GPI} \operatorname{IgG} / \mathrm{M}$ in $30(46 \%)$ and $4(9 \%)$, respectively.

The age of APS patients was higher than in patients with non-conventional APS (40 \pm 9 versus $32 \pm 5$ years; $p<0.0001)$. The obstetrical history, the number of uncomplicated pregnancies and live births, as well as the frequencies of recurrent miscarriages, intrauterine fetal deaths and premature deliveries did not differed between the 3 groups. The frequency of associated thrombosis was also similar (Table 2). The frequencies of anti-annexin V IgG antibodies tended to be more frequent in non-conventional APS with a $15 \%$ difference (88\% versus $73 \% ; \mathrm{p}=0.06$ ), and those of anti-PE IgG and $\mathrm{M}$ were similar in comparison with confirmed APS. The anti-PS/PT IgG and M antibodies were significantly more frequent in confirmed APS than in non-conventional APS $(63 \%$ and $37 \%$ versus $4 \%$ and $5 \%$, respectively, $\mathrm{p}<0.0001)$. Anti-domain I $\beta 2 \mathrm{GPI}$ antibodies were showed in $50 \%$ of confirmed APS and only $4 \%$ of non-conventional APS ( $\mathrm{p}<0.0001$ ). IgA anti- $\beta 2$ GPI antibodies were exclusively present in patients with confirmed APS in $9(41 \%)$ out of the 22 available cases.

There was no association between the type of non-conventional APL and any type of obstetrical events (recurrent miscarriages, prematurity, intrauterine fetal death or preeclampsia) or thrombosis in non-conventional APS and APS groups.

\section{Pregnancies outcome and treatment}

Overall 261 pregnancies which occurred in 65 patients with non-conventional APS were compared to 81 pregnancies of confirmed APS patients and 132 pregnancies of 31 patients from non-APL group.

Considering 474 pregnancies from all 3 groups (Table 3), the rate of pregnancies losses without any treatment was quite similar in all groups, with $64 \%$ in non-APL group, $74 \%$ in APS and $75 \%$ in non-APL group. 136/474 (29\%) patients have been treated during pregnancies and treatment significantly increased the rate of live birth $(26 \%$ in untreated versus $72 \%$ in treated pregnancies, $\mathrm{p}<0.0001)$. The number of treated pregnancies tended to be more frequent in APS patients $(\mathrm{n}=33 ; 41 \%)$ in comparison to non-conventional APS $(\mathrm{n}=67 ; 26 \%)$ and non-APL group $(\mathrm{n}=36 ; 27 \%)(\mathrm{p}=0.05)$. The aspirin-low-molecular weight heparin (LMWH) combination was used more frequently in APS patients $(n=19 / 33 ; 58 \%)$ in comparison to non-conventional APS $(n=19 / 67 ; 28 \%)$ and non-APL group $(n=17 / 36 ; 47 \%)$ 


\section{ACCEPTED MANUSCRIPT}

$(\mathrm{p}<0.05)$. In univariate analyses, treatment effect on pregnancies losses was similar in patients with APS and non-conventional APS, with odds ratio at 3.3 [95\% CI; 1.8 to 6.1] and 6.9 [95\% CI; 3.9 to 12.3] ( $\mathrm{p}=0.49)$ and significantly more important for the 2 APS groups pooled versus non-APL group (OR at 1.9 [95\% CI; 1.1 to 3.5] for non-APL group versus 5.3 [95\% CI; 3.5 to 8.1] for APS groups, $\mathrm{p}=0.0025$ ).

In univariate analysis, the number of complicated pregnancies, the treatment during pregnancies in particular in APS and non-conventional APS groups, was significantly associated with live births (Table 3). In multivariate analysis, the pregnancy treatment and less previous complicated pregnancies were independently associated with live births (Table 3).

\section{Discussion}

In the present study, we show that the non-conventional antiphospholipid antibodies could be detected in patients with APS-defined obstetrical adverse events without any conventional APL. Among the non-conventional antibodies, mainly anti-annexin V IgG and anti-PE antibodies were significantly associated with adverse obstetrical events. Conventional APS treatment (aspirin and LMWH alone and/or in combination) dramatically improved the obstetrical outcome in patients with non-conventional APL. Non-conventional APL displayed different profiles, with anti-annexin V IgG and anti-PE in non-conventional APS and antiPS/PT IgG/M and IgA anti- $\beta 2$ GPI antibodies in patients with confirmed APS.

In the absence of standardized method for non-conventional APL, the cut-offs need to be established, as they could vary in different clinical subsets and conditions. We have previously demonstrated that IgG/M ACL and anti- $\beta 2$ GPI levels are lower in healthy newborns than in healthy pregnant and non-pregnant women [6]. Low levels of APL have been included in several studies of obstetrical APS, in patients with thrombosis and aspirinLMWH combination could improve the pregnancy outcome in patients with low APL titers [7] [8] [9]. Only one study has previously determined the non-conventional anti-PE and antiannexin V cut-offs in comparison to healthy controls [5]. We used ROC analysis to determine the cut-off of each APL. Anti-annexin V IgG and anti-PE IgG antibodies were sufficient to discriminate patients with clinical APS from healthy controls with AUC at 0.93 and 0.82 (Odds ratio at 0.482 [0.343 to 0.625$]$ and 0.84 [0.64 to 1.076$]$, respectively).

The presence of obstetrical and/or thrombotic features in the absence of conventional APL has previously been termed as "seronegative APS". Rodriguez-Garcia et al. described patients with non-criteria APS without APL which have similar thrombotic and pregnancy morbidity in comparison to confirmed APS [10]. In our study, patients with and without conventional APL have similar frequencies of thrombotic and pregnancy complications, as well the number of live births. In patients with APS-like features, it was thus hypothesized that antibodies against other phospholipids or cofactors, such as prothrombin, phosphatidylethanolamine or annexin V, could be detected [10]. Several studies reported various non-conventional APL in patients with thrombosis and pregnancy morbidity, but relatively few data are yet available. Significantly more anti-PE APL have been found in 98 patients with unexplained thrombosis, 


\section{ACCEPTED MANUSCRIPT}

with mean levels similar to APS patients [11]. Among 743 women with recurrent early spontaneous abortion, higher levels of anti-PE IgM, anti-annexin V IgG have been found in comparison to matched controls [5]. Considering APL levels by percentiles, anti-PE IgG and $\mathrm{M}$, anti-annexin V IgG but not IgM were significantly associated with spontaneous abortion at titers $>80 \mathrm{e}$ percentiles with increasing odds ratio with percentiles [5]. Anti-annexin V antibodies have been found in $19 \%$ of patients with recurrent early miscarriages with similar frequency in healthy controls [12]. Anti-PS/PT APL seem to be rare in patients with nonconventional APS, and were found in 12/169 (6.5\%) patients in previous study and $4-5 \%$ in our cohort [13]. Isolated IgA anti- $\beta 2 \mathrm{GPI}$ antibodies have been found in $22.4 \%$ of clinical APS, even more frequently than $15 \%$ of $\mathrm{IgG} / \mathrm{M}$ anti- $\beta 2 \mathrm{GPI}$ conventional antibodies, but only APS patients have detectable IgA anti- $\beta 2$ GPI APL in our study [14]. Anti- $\beta 2$ GPI domain I antibodies have been found in $3 / 40(7.5 \%)$ of patients with seronegative APS in a previous report, similarly to $4.1 \%$ of non-conventional APS in our report [15].

No studies previously assessed the possible benefit of treatment during the pregnancy in patients with non-conventional APL. In our study, pregnancy treatment significantly increased the live birth rate in non-conventional APS, with similar effect to confirmed APS, and significantly more than in patients without any APL. Aspirin-LMWH combination was significantly less frequent in non-conventional APS, whereas the number of pregnancies with favorable outcome was similar. Even this point could suggest that monotherapy with aspirin or LMWH could be sufficient in non-conventional APS, studies are needed to determine the best regimen in these patients. In univariate analysis, pregnancy loss in patients under hydroxychloroquine was dropped to $17 \%$ from $60 \%$ without hydroxychloroquine. Even not significant in multivariate analysis, the number of patients under hydroxychloroquine was small. Recent preliminary studies in obstetrical APS showed that hydroxychloroquine could be effective drug in addition to aspirin-LMWH combination for obstetrical outcome [16].

Even if non-conventional APL could be detected, one should try to demonstrate its pathogenic link with the underlying clinical features. Only one experimental study actually demonstrated that passive immunization of aPE in mice resulted in increase of fetal resorption, placental thrombosis and apoptosis with decreased trophoblastic cell invasion [17].

Our study has several limitations which could strain the definite conclusions. First, nonconventional APL have not been systematically controlled, or were controlled under aspirin and heparin combination and we could not confirm their persistence in all positive cases. Nevertheless, precise clinical history allows us to exclude other situations which could be associated with transitory autoantibodies, as infectious and neoplastic conditions. Most of the previous studies which assessed the non-conventional APL also failed to analyze the persistence of these APL. The use of various treatment regimens did not allow us to determine the impact of such drug, as steroids and hydroxychloroquine, and the best regimen for patients with non-conventional APS remain to be determined. 


\section{Conclusion}

Our study shows the interest to detect the non-conventional APL in patients with APS-like obstetrical features. Treatment during pregnancy in these patients dramatically improves the pregnancy outcome. Prospective studies are warranted to confirm the benefit of treatment for patients with non-conventional APL and determine the best regimen.

\section{References.}

[1] Gomez-Puerta JA, Cervera R. Diagnosis and classification of the antiphospholipid syndrome. J Autoimmun. 2014 Feb-Mar;48-49:20-5.

[2] Nayfe R, Uthman I, Aoun J, Saad Aldin E, Merashli M, Khamashta MA. Seronegative antiphospholipid syndrome. Rheumatology (Oxford). 2013 Aug;52(8):1358-67.

[3] Sauer R, Roussev R, Jeyendran RS, Coulam CB. Prevalence of antiphospholipid antibodies among women experiencing unexplained infertility and recurrent implantation failure. Fertil Steril. 2010

May 1;93(7):2441-3.

[4] Gris JC, Quere I, Sanmarco M, Boutiere B, Mercier E, Amiral J, et al. Antiphospholipid and antiprotein syndromes in non-thrombotic, non-autoimmune women with unexplained recurrent primary early foetal loss. The Nimes Obstetricians and Haematologists Study--NOHA. Thromb Haemost. 2000 Aug;84(2):228-36.

[5] Gris JC, Perneger TV, Quere I, Mercier E, Fabbro-Peray P, Lavigne-Lissalde G, et al. Antiphospholipid/antiprotein antibodies, hemostasis-related autoantibodies, and plasma homocysteine as risk factors for a first early pregnancy loss: a matched case-control study. Blood. 2003 Nov 15;102(10):3504-13.

[6] Nicaise-Roland P, Aurousseau MH, Delaval A, Grootenboer-Mignot S, Hurtado M, Carbillon L, et al. Levels of anticardiolipin and anti-beta(2)-glycoprotein I antibodies in healthy newborn cord sera. Thromb Haemost. 2008 Jun;99(6):1124-6.

[7] Reznikoff-Etievant MF, Cayol V, Zou GM, Abuaf N, Robert A, Johanet C, et al. Habitual abortions in 678 healthy patients: investigation and prevention. Hum Reprod. 1999 Aug;14(8):2106-9.

[8] Amaral M, Favas C, Delgado Alves J. Persistency of low levels of anticardiolipin and anti-beta2 glycoprotein1 in thrombosis. Eur J Intern Med. 2010 Apr;21(2):101-3.

[9] Mekinian A, Loire-Berson P, Nicaise-Roland P, Lachassinne E, Stirnemann J, Boffa $\mathrm{MC}$, et al. Outcomes and treatment of obstetrical antiphospholipid syndrome in women with low antiphospholipid antibody levels. J Reprod Immunol. 2012 Jun;94(2):222-6.

[10] Rodriguez-Garcia JL, Bertolaccini ML, Cuadrado MJ, Sanna G, Ateka-Barrutia O, Khamashta MA. Clinical manifestations of antiphospholipid syndrome (APS) with and without antiphospholipid antibodies (the so-called 'seronegative APS'). Ann Rheum Dis. 2012 Feb;71(2):242-4.

[11] Sanmarco M, Alessi MC, Harle JR, Sapin C, Aillaud MF, Gentile S, et al. Antibodies to phosphatidylethanolamine as the only antiphospholipid antibodies found in patients with unexplained thromboses. Thromb Haemost. 2001 May;85(5):800-5.

[12] Arnold J, Holmes Z, Pickering W, Farmer C, Regan L, Cohen H. Anti-beta 2 glycoprotein 1 and anti-annexin $\mathrm{V}$ antibodies in women with recurrent miscarriage. $\mathrm{Br} \mathrm{J}$ Haematol. 2001 Jun;113(4):911-4. 


\section{ACCEPTED MANUSCRIPT}

[13] Zigon P, Perdan Pirkmajer K, Tomsic M, Kveder T, Bozic B, Sodin Semrl S, et al. Anti-Phosphatidylserine/Prothrombin Antibodies Are Associated with Adverse Pregnancy Outcomes. J Immunol Res. 2015;2015:975704.

[14] Ruiz-Garcia R, Serrano M, Martinez-Flores JA, Mora S, Morillas L, Martin-Mola $\mathrm{MA}$, et al. Isolated IgA anti- beta2 glycoprotein I antibodies in patients with clinical criteria for antiphospholipid syndrome. J Immunol Res. 2014;2014:704395.

[15] Cousins L, Pericleous C, Khamashta M, Bertolaccini ML, Ioannou Y, Giles I, et al. Antibodies to domain I of beta-2-glycoprotein I and IgA antiphospholipid antibodies in patients with 'seronegative' antiphospholipid syndrome. Ann Rheum Dis. 2015 Jan;74(1):3179.

[16] Mekinian A, Lazzaroni MG, Kuzenko A, Alijotas-Reig J, Ruffatti A, Levy P, et al. The efficacy of hydroxychloroquine for obstetrical outcome in anti-phospholipid syndrome: Data from a European multicenter retrospective study. Autoimmun Rev. 2015 Jun;14(6):498502.

[17] Velayuthaprabhu S, Matsubayashi H, Sugi T, Nakamura M, Ohnishi Y, Ogura T, et al. A unique preliminary study on placental apoptosis in mice with passive immunization of antiphosphatidylethanolamine antibodies and anti-factor XII antibodies. Am J Reprod Immunol. 2011 Nov;66(5):373-84.

\section{Acknowledgements}

Funding Sources: none.

Conflicts of interest: none.

\section{AUTHOR CONTRIBUTIONS}

All authors were involved in drafting the article. Arsene Mekinian and Pascale NicaiseRoland have full access to all of the data in the study and takes responsibility for the integrity of the data and the accuracy of data analysis.

Study conception and design. AM, LC, OF, PNR.

Acquisition of data. AM, BMC, FM, LC, AM, AT, SCM, OF, PNR.

Analysis and interpretation of data. AM, FM, OF, PNR. 


\section{ACCEPTED MANUSCRIPT}

Table 1. Non-conventional APL: cut-offs from 96 patients with clinical APS in comparison to 47 healthy pregnant controls (ROC analysis).

\begin{tabular}{|l|c|c|c|c|c|c|c|}
\hline APL & $\begin{array}{c}\text { Cut-off } \\
\text { U/ml }\end{array}$ & Sensibility & Specificity & AUC & \multicolumn{2}{|c|}{ Odds Ratio Estimates* } & \multicolumn{2}{|c|}{ 95\% CI } \\
\hline Anti-Annexin V IgG & 6 & $98 \%$ & $60 \%$ & 0.93 & 0.48 & 0.34 & 0.63 \\
\hline Anti-PE IgG & 6 & $94 \%$ & $46 \%$ & 0.82 & 0.85 & 0.65 & 1.08 \\
\hline Anti-PE IgM & 6 & $72 \%$ & $39 \%$ & 0.64 & 0.97 & 0.87 & 1.07 \\
\hline Anti-PS/PT IgG & 15 & $9 \%$ & $93 \%$ & 0.54 & 1.01 & 0.92 & 1.09 \\
\hline Anti-PS/PT IgM & 13 & $40 \%$ & $74 \%$ & 0.62 & 1.03 & 0.94 & 1.14 \\
\hline
\end{tabular}

* OR for an increase of 1 unit of the Non-conventional APL variable

Table 2. Characteristics of patients with confirmed APS, non-conventional APS and non-APL group.

\begin{tabular}{|c|c|c|c|}
\hline & $\begin{array}{l}\text { Non-conventional APS } \\
\qquad \mathrm{N}=65\end{array}$ & $\begin{array}{c}\text { Confirmed APS } \\
\mathrm{N}=83\end{array}$ & $\begin{array}{l}\text { Non-APL group } \\
\qquad \mathbf{N}=31\end{array}$ \\
\hline Obstetrical history & & & \\
\hline Age (years) & $32 \pm 5(n=64)$ & $40 \pm 9 *(n=78)$ & $35 \pm 6^{* * *}(\mathrm{n}=29)$ \\
\hline Normal pregnancies & $39 / 64(60 \%)$ & $30 / 46(65 \%)$ & $20 / 31(65 \%)$ \\
\hline Number of normal pregnancies & $1.0 \pm 1.0$ & $1.2 \pm 1.4$ & $1.0 \pm 1.3$ \\
\hline Recurrent Miscarriages & $28 / 65(43 \%)$ & $18 / 45(38 \%)$ & $16 / 31(52 \%)$ \\
\hline Intrauterine fetal deaths & $29 / 65(45 \%)$ & $19 / 47(40 \%)$ & $9 / 30(30 \%)$ \\
\hline Prematurity <34 wg & $14 / 64(22 \%)$ & $11 / 41(27 \%)$ & $11 / 30(37 \%)$ \\
\hline Preeclampsia/ HELLP & $12 / 65(18 \%) / 3 / 65(5 \%)$ & $8 / 46(17 \%) / 1 / 18(6 \%)$ & $8 / 30(27 \%) / 2 / 31(7 \%)$ \\
\hline Live-born babies & $1.4 \pm 1.0(\mathrm{n}=64)$ & $1.6 \pm 0.9(n=16)$ & $1.6 \pm 1.4(\mathrm{n}=31)$ \\
\hline $\begin{array}{l}\text { Thrombosis history } \\
\text { Thrombosis number }\end{array}$ & $\begin{array}{c}10 / 65(15 \%) \\
0.2 \pm 0.4\end{array}$ & $\begin{array}{c}12 / 48(25 \%) \\
0.3 \pm 0.5\end{array}$ & $\begin{array}{c}4 / 31(13 \%) \\
0.2 \pm 0.5\end{array}$ \\
\hline Anti-Annexin V IgG & $57 / 65(88 \%)$ & $38 / 52(73 \%)(\mathrm{p}=0.057)$ & 0 \\
\hline$\overline{\text { Anti-PE IgG }}$ & $39 / 61(60 \%)$ & $26 / 50(52 \%)$ & 0 \\
\hline$\overline{\text { Anti-PE IgM }}$ & $8 / 61(12 \%)$ & $4 / 50(8 \%)$ & 0 \\
\hline Anti-PS/PT IgG & $2 / 56(3 \%)$ & $31 / 49(63 \%)^{*}$ & 0 \\
\hline Anti-PS/PT IgM & $3 / 56(5 \%)$ & $18 / 49(37 \%)^{*}$ & 0 \\
\hline Anti-domain I $\beta 2$ GPI & $2 / 49(3 \%)$ & $12 / 24(50 \%)^{*}$ & 0 \\
\hline 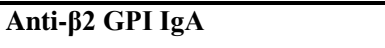 & 0 & $9 / 22(41 \%)^{*}$ & 0 \\
\hline
\end{tabular}




\begin{tabular}{|c|c|c|c|}
\hline \multicolumn{4}{|c|}{ ACGEPTED MANUSCRIPT } \\
\hline Pregnancies treatment & $\mathrm{N}=261$ & $\mathrm{~N}=81$ & $\mathrm{~N}=132$ \\
\hline Treated pregnancies & $67(26 \%)$ & $33(41 \%)^{*}$ & $36(27 \%)$ \\
\hline Aspirin /LMWH alone & $35(13 \%)$ & $11(14 \%)$ & $14(11 \%)$ \\
\hline Aspirin-LMWH & $19(7 \%)$ & $19(24 \%)^{*}$ & $17(13 \%)^{* * * *}$ \\
\hline Prednisone & $12(5 \%)$ & $3(4 \%)$ & $5(4 \%)$ \\
\hline Hydroxychloroquine & $7(3 \%)$ & $3(4 \%)$ & $2(2 \%)$ \\
\hline $\begin{array}{l}\text { Neonates characteristics } \\
\text { (last pregnancy) }\end{array}$ & $\mathrm{N}=64$ & $\mathrm{~N}=18$ & $\mathrm{~N}=31$ \\
\hline Birth weight (gr) & $3823 \pm 4238(n=26)$ & $3064 \pm 722(n=9)$ & $2330 \pm 724 * * *(\mathrm{n}=10)$ \\
\hline SGA $(<10 e$ percentile $)$ & $10 / 27(37 \%)$ & $12 / 18(67 \%)$ & $6 / 11(54 \%)$ \\
\hline Apgar 10 / IU admission & $26 / 28(93 \%) / 1(3 \%)$ & $10 / 10(100 \%) / 1(9 \%)$ & $11 / 11(100 \%) / 2(14 \%)$ \\
\hline
\end{tabular}

Values are means with SD and numbers with frequencies and data are expressed considering the missing data.

$*_{\mathrm{p}}<0.05$ Non-conventional APS vs APS

$* * \mathrm{p}<0.05$ Non-conventional APS vs non-APL group

$* * * \mathrm{p}<0.05$ Non-APL group vs APS

Table 3. Factors associated with pregnancies losses of 474 pregnancies of patients with confirmed APS, non-conventional APS and non-APL group (univariate and multivariate analysis).

\begin{tabular}{|c|c|c|c|c|}
\hline Parameter & \%Pregnancy losses & $\begin{array}{l}\text { OR univariate } \\
{[95 \% \mathrm{CI}]}\end{array}$ & $\begin{array}{l}\text { p-value } \\
\text { multivariate }\end{array}$ & $\begin{array}{ll}\text { OR } & \text { multivariate } \\
{[95 \%} & \mathrm{CI}]\end{array}$ \\
\hline $\begin{array}{l}\text { Group } \\
\text { APS (at risk) } \\
\text { Non-conventional APS } \\
\text { Non-APL group }\end{array}$ & $\begin{array}{l}\text { 158/261: } 61 \% \\
48 / 81: 59 \% \\
75 / 132: 57 \%\end{array}$ & $\begin{array}{l}0.93[0.56 \text { to } 1.55] \\
0.87[0.57 \text { to } 1.34]\end{array}$ & 0.56 & $\begin{array}{l}1.16[0.63 \text { to } 2.14] \\
0.85[0.52 \text { to } 1.41]\end{array}$ \\
\hline $\begin{array}{l}\text { Pregnancy Treatment } \\
\text { Treated } \\
\text { Untreated }\end{array}$ & $\begin{array}{l}\text { 36/136: } 26 \% \\
\text { 245/338: } 72 \%\end{array}$ & $0.14[0.09$ to 0.22$]$ & $<0.0001$ & 0.14 [0.08 to 0.22$]$ \\
\hline $\begin{array}{l}\text { Type of Pregnancy Treatment } \\
\text { None (at risk) } \\
\text { Aspirin or LMWH alone } \\
\text { Aspirin and LMWH } \\
\text { Other }\end{array}$ & $\begin{array}{l}245 / 338: 72 \% \\
22 / 60: 37 \% \\
9 / 55: 16 \% \\
5 / 21: 24 \%\end{array}$ & $\begin{array}{l}0.23[0.13 \text { to } 0.40] \\
0.08[0.04 \text { to } 0.17] \\
0.13[0.04 \text { to } 0.36]\end{array}$ & Not included & \\
\hline $\begin{array}{l}\text { Type of Pregnancy Treatment by Group } \\
\text { APS untreated (at risk) } \\
\text { APS treated } \\
\text { - } \quad \text { Aspirin or LMWH alone } \\
\text { - } \quad \text { Aspirin and LMWH } \\
\text { - Other }\end{array}$ & $\begin{array}{l}\text { 146/194: } 75 \% \\
\text { 10/33: } 30 \% \\
7 / 34: 21 \% \\
\text { 3/18: } 17 \% \\
\text { 2/13: } 15 \%\end{array}$ & 3.35 [1.84 to 6.07$]$ & $\begin{array}{l}0.0125 \\
<0.0001\end{array}$ & 9.91 [3.38 to 29.07] \\
\hline
\end{tabular}




\section{ACCEPTED MANUSCRIPT}

\begin{tabular}{|c|c|c|c|c|}
\hline $\begin{array}{l}\text { Non-conventional APS untreated (at risk) } \\
\text { Non-conventional APS treated } \\
\text { - Aspirin or LMWH alone } \\
\text { - Aspirin and LMWH } \\
\text { - Other } \\
\text { Non-APL group untreated (at risk) } \\
\text { Non-APL group treated } \\
\text { - Aspirin or LMWH alone } \\
\text { - Aspirin and LMWH } \\
\text { - Other }\end{array}$ & $\begin{array}{l}\text { 38/48: } 79 \% \\
\text { 12/65: } 18 \% \\
\text { 6/11: } 55 \% \\
\text { 3/19: } 16 \% \\
\text { 1/3: } 33 \% \\
\text { 61/96: } 64 \% \\
\text { 14/34: } 41 \% \\
\text { 9/14: } 64 \% \\
\text { 3/16: } 19 \% \\
\text { 2/4:50\% }\end{array}$ & $\begin{array}{l}6.91[3.89 \text { to } 12.27] \\
1.95[1.08 \text { to } 3.51]\end{array}$ & $<0.0001$ & $\begin{array}{l}13.05 \quad[6.16 \quad \text { to } \\
24.54] \\
2.47[1.06 \text { to } 5.79]\end{array}$ \\
\hline $\begin{array}{l}\text { Aspirin } \\
\text { Yes } \\
\text { No }\end{array}$ & $\begin{array}{l}\text { 32/118: } 27 \% \\
\text { 249/356: } 70 \%\end{array}$ & $0.16[0.10$ to 0.26$]$ & Not included & \\
\hline $\begin{array}{l}\text { LMWH } \\
\text { Yes } \\
\text { No }\end{array}$ & $\begin{array}{l}\text { 15/81: } 19 \% \\
\text { 266/393: } 68 \%\end{array}$ & $0.12[0.06$ to 0.21$]$ & Not included & \\
\hline $\begin{array}{l}\text { Steroids } \\
\text { Yes } \\
\text { No } \\
\end{array}$ & $\begin{array}{l}\text { 5/20: } 25 \% \\
\text { 276/454: } 61 \%\end{array}$ & $0.23[0.08$ to 0.64$]$ & Not included & \\
\hline $\begin{array}{l}\text { Hydroxychloroquine } \\
\text { Yes } \\
\text { No }\end{array}$ & $\begin{array}{l}\text { 2/12: } 17 \% \\
\text { 279/462: } 60 \%\end{array}$ & $0.13[0.03$ to 0.59$]$ & Not included & \\
\hline $\begin{array}{l}\text { Age } \\
>30 \text { years } \\
\leq 30 \text { years }\end{array}$ & $\begin{array}{l}\text { 176/316: } 56 \% \\
87 / 132: 66 \%\end{array}$ & $1.49[0.98$ to 2.28$]$ & Not included & \\
\hline $\begin{array}{l}\text { Uncomplicated pregnancies } \\
\text { None } \\
\text { At least one or more }\end{array}$ & $\begin{array}{l}\text { 170/318: } 55 \% \\
\text { 110/155: } 71 \%\end{array}$ & 2.20 [1.45 to 3.33$]$ & 0.0002 & $2.06[1.27$ to 3.36$]$ \\
\hline $\begin{array}{l}\text { Complicated pregnancies } \\
\leq 2 \\
>2\end{array}$ & $\begin{array}{l}\text { 34/107: } 32 \% \\
246 / 366: 67 \% \\
\end{array}$ & $0.22[0.14$ to 0.35$]$ & $<0.0001$ & 0.30 [0.17 to 0.89$]$ \\
\hline $\begin{array}{l}\text { Thrombosis } \\
\text { Yes } \\
\text { No } \\
\end{array}$ & $\begin{array}{l}\text { 32/67: } 48 \% \\
\text { 249/407: } 61 \%\end{array}$ & $0.59[0.35$ to 0.99$]$ & NS & \\
\hline $\begin{array}{l}\text { Isolated early recurrent miscarriages } \\
\text { Yes } \\
\text { No }\end{array}$ & $\begin{array}{l}\text { 137/277: } 49 \% \\
\text { 249/407: } 61 \%\end{array}$ & 2.92 [1.96 to 4.35$]$ & $\mathrm{NS}(\mathrm{p}=0.054)$ & 1.66 [0.99 to 2.77$]$ \\
\hline
\end{tabular}

NS: non-significant; APS: antiphospholipid syndrome; LMWH: low-molecular weighted heparin. 


\section{ACCEPTED MANUSCRIPT}

Figure 1. ROC analysis of non-conventional APL in patients with clinical APS without conventional APL antibodies: anti-annexin V IgG and anti-PE IgG are sufficient to discriminate patients with clinical APS from healthy controls.

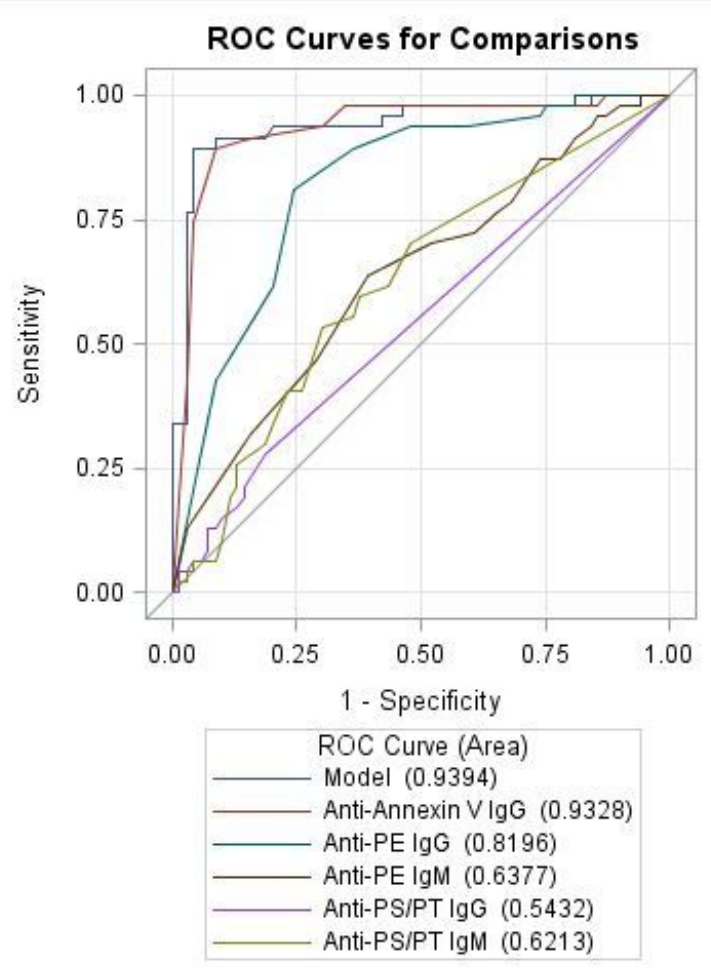

